Portland State University

PDXScholar

\title{
A New Perspective on Late Holocene Social Interaction in Northwest Alaska: Results of a Preliminary Ceramic Sourcing Study
}

\author{
Shelby L. Anderson \\ Portland State University, ashelby@pdx.edu \\ Matthew T. Boulanger \\ University of Missouri \\ Michael D. Glascock \\ University of Missouri
}

Follow this and additional works at: https://pdxscholar.library.pdx.edu/anth_fac

Part of the Archaeological Anthropology Commons, and the Social and Cultural Anthropology Commons

Let us know how access to this document benefits you.

\section{Citation Details}

Anderson, Shelby L.; Boulanger, Matthew T.; and Glascock, Michael D., "A New Perspective on Late Holocene Social Interaction in Northwest Alaska: Results of a Preliminary Ceramic Sourcing Study" (2010). Anthropology Faculty Publications and Presentations. 31.

https://pdxscholar.library.pdx.edu/anth_fac/31

This Post-Print is brought to you for free and open access. It has been accepted for inclusion in Anthropology Faculty Publications and Presentations by an authorized administrator of PDXScholar. Please contact us if we can make this document more accessible: pdxscholar@pdx.edu. 


\title{
A new Perspective on Late Holocene Social Interaction in NorthWest Alaska: Results of a Preliminary Ceramic Sourcing Study
}

Shelby L. Anderson (corresponding author) ${ }^{\mathrm{a}}$ shelbya@u.washington.edu, 206-543-5240

${ }^{a}$ University of Washington, Department of Anthropology, Box 353100, Seattle, WA 981953100, USA

Matthew T. Boulanger b boulangerm@missouri.edu, 573-882-5260

Michael D. Glascock ${ }^{\mathrm{b}}$ glascockm@missouri.edu, 573-882-5270

${ }^{\mathrm{b}}$ Archaeometry Laboratory, University of Missouri Research Reactor, 1513 Research Park Drive, Columbia, MO 65211, USA

\begin{abstract}
This research examines the evidence for prehistoric ceramic exchange networks over the last 2,000 years in northwest Alaska through the use of neutron activation analysis of ceramic artifacts. Results from ceramic analysis on eight coastal and inland archaeological sites identified three source macrogroups and three associated subgroups. Clay source diversity and shared source macrogroups between geographically distant sites suggest the use of multiple sources and/or the movement of pots between production locales, mirroring related patterns in pottery stylistic data. Although additional analytical work is needed to fully understand the changing character of clay procurement and ceramic distribution across this time period, this study provides exploratory data on past ceramic production and distribution that hints at changes in exchange and territoriality in northwest Alaska during the late Holocene.
\end{abstract}

Keywords: exchange, social complexity, hunter-gatherers, ceramics, neutron activation analysis, northwest Alaska

\section{INTRODUCTION}

Northwest Alaska witnessed the emergence of socio-political and economic complexity in the two millennia before European contact in the $19^{\text {th }}$ century (Mason 1998, Savelle and Wenzel 2003, Sheehan 1997, Whitridge 1999). Evidence of complexity, peaking around 1000 years ago in northwest Alaska, includes large semi-subterranean structures, differential burial practices, increased warfare and inter-personal violence, development of food storage, and high settlement density at places with rich and predictable resources on the outer Kotzebue Sound (Mason 1998; see Figure 1). The large-scale subsistence whale hunting, intercontinental exchange networks and extensive coastal settlements of the Bering Strait and Chukchi Sea coasts are unprecedented in the anthropological literature of hunter-gatherer groups in other regions. By the $19^{\text {th }}$ century, the Inupiat of northwest Alaska lived in at least ten highly territorial yet interdependent 'nations' that were further organized into compound or corporate groups (Burch 1998, 2005, 2006, Ray 1992). Conflict and violence were common, often arising over competition for resources; however, cooperation was also a central aspect of past lifeways in the Arctic. People across the region maintained and depended on far-reaching social and exchange networks (Burch 2005). Knowledge of this historic pattern has heavily influenced archaeological interpretations of prehistoric social organizations and social change, despite evidence that these systems underwent dramatic change in the $17^{\text {th }}$ and 18th centuries, prior to direct contact with Russians and EuroAmericans (VanStone and Goddard 1981). 
Archaeological research on the emergence of social inequality in this region has focused on how and when complexity and inequality emerged in egalitarian hunter-gatherer groups. The mechanisms that drove changes in the economy, social status, and the social lives of these people remain poorly understood. In northwest Alaska, previous studies have generally focused on environmental factors that contributed to the development of complex social organization in arctic hunter-gatherer groups (Mason and Gerlach 1995a, 1995b, Mason 1998, Mason and Barber 2003, Sheehan 1997). Environmental variability was likely a critical factor in social evolution (Yesner 1998), however, other potential factors in the emergence of inequality and complexity - such as population pressure, sedentism (Binford 1980, 2001; Kelly 2000), exchange systems, territoriality, resource abundance (Hayden 1994, 1995), control of labor or resource access (Arnold 1993; 1996a;1996b; Hayden 1995), or a combination of these factors (Fitzhugh 2003)- have not been fully explored. Although the literature on complex hunter-gatherers is expanding (eg. Ames and Maschner 1999, Arnold 1996b, Price and Feinman 1995; Kennett 2005, Sassaman 2004) a clear understanding of the processes driving social change in the North has not yet been achieved.

This research brings a new line of evidence, pottery compositional and stylistic data, to bear on questions of changing social interaction during the last 2000 years in northwest Alaska. The focus of this exploratory study is on one aspect of complex social organizations, exchange networks. As the first large-scale ceramic sourcing study in the region, the goals of this project are: 1) to establish that ceramic data can be used to address questions about social interaction and organization; 2) to evaluate hypotheses about the nature of past pottery production and distribution; and 3) to determine whether or not there is evidence of pre- $19^{\text {th }}$ century ceramic exchange across the region. These data will provide new insight into past territoriality, exchange systems, and social interaction in northwest Alaska before the $19^{\text {th }}$ century. Furthermore, this preliminary sourcing study provides a basis for studying raw material procurement practices as a proxy for understanding social change by examining exchange systems, increasing territoriality and competition through study of labor and resource control and the development of low-level ceramic specialization. The potential for an expanded ceramic study to further explore the mechanisms underlying emergent social complexity in northwest Alaska is considered in section 6.

\section{BACKGROUND \\ 2.1 Cultural Context}

The culture history of northwest Alaska was influenced by people living on both sides of the Bering Strait (Burch 2005, Ray 1992). Some of the earliest sites in North America are found in the Alaska Interior, and coastal sites are known from the Pacific coast of southern Alaska as early as 10,000 years ago. Interior northwest Alaskan Paleoarctic sites reflect a full-time terrestrial hunting orientation until about 4000 years ago, when there was a shift toward seasonal occupation of the coast. Earlier coastal sites, however, may have been obscured by rising sealevel (Brigham-Grette et al. 2004, Erlandson, et al. 2008). Between about 4000 and 1450 years ago significant changes in settlement patterns, subsistence and technology took place as marine hunting and fishing became increasingly important. By 3600 years ago site distributions suggest that some people began to live on the coast full time while interior groups maintained a more transitory seasonal pattern, likely focused on caribou resources. Coastal populations continued to 
increase and by 1450 years ago people in the Bering Strait region and beyond were competing for the best sea mammal hunting areas (Mason 1998, Mason and Barber 2003, Whitridge 1999).

The subsequent Neoeskimo period (approximately 1450 to 300 years ago) encompasses considerable technological and subsistence variability, as well as evidence of increasing settlement size, economic complexity, and the emergence of social difference (Anderson 1984, Dumond 1977, Giddings and Anderson 1986, Mason 1998). Approximately 500 years ago, the character of settlements across the region changed, with the exception of the largest whaling villages in places like Point Hope and Barrow where population levels and settlement density remained high. Overall, settlements became more dispersed and population may have decreased across the region after 500 years ago, perhaps in response to changing climate and related marine mammal availability (Anderson 1984). During this same time period a woodland or river culture emerged (Anderson 1977, 1988, Anderson et al. 1998, Giddings 1952, Hall 1971, 1976, Hickey 1968, 1977, Shirar 2009), possibly as coastal people dispersed into the interior (Mason and Barber 2003).

\subsection{Hunter-Gatherer Ceramics in the North}

Although pottery was in use in Japan and in the Amur River region of the Russian Far East between 13,000-10,000 years ago (Jordan and Zvelebil 2009, McKenzie 2009, Zhushchikohovskaya 1997, 2005, 2009) and on the interior Chukotka Peninsula by about 5000 years ago (Mochanov and Powers 1969a, b), people in Alaska did not begin to use pottery until 3000-3500 years ago (Giddings and Anderson 1986, Irving 1962, Stanford 1976) when pottery was also widely used along the eastern Bering Sea Coast (Ponkratova 2006). Following this initial adoption of pottery technology from Siberia, pottery spread rapidly north and east into the Canadian Arctic and south to the Alaska Peninsula, reaching Kodiak Island in Southwest Alaska by 1000 years ago (Clark 1984, Dumond 1984). This rapid adoption of Siberian pottery technology suggests that pottery quickly became an integral part of subsistence and economy in the North American Arctic.

Coastal peoples abandoned key elements of Norton technology, including pottery, during the subsequent Ipiutak culture period (ca. 1900-1000 years ago). Pottery, however, is reported from contemporary interior sites (Lucier and VanStone 1992). Beginning around 1450 years ago, Neoeskimo or Thule pottery technology replaced Norton pottery across Alaska. In the $19^{\text {th }}$ century, the Inupiat living on the outer Kotzebue Sound (Burch 1998) reportedly made relatively crude clay vessels and imported better constructed and decorated vessels from the Buckland and Selawik river regions, and from Wales. Pottery was also exchanged between Wales and inhabitants of southern Seward Peninsula (Kugzruk 1987). People living on the Noatak River reportedly traded for pottery from the Selawik region (Giddings 1952, Lucier and VanStone 1992) and pottery exchange is reported in other parts of northern Alaska as well (de Laguna 1947, Lucier and VanStone 1992, Nelson 1983, Osgood 1940, Spencer 1959, Stefansson and Wissler 1914, Stoney 1900, VanStone 1954). It is clear, however, that pottery production rapidly decreased as metal pots became more widely available across the region in the $18^{\text {th }}$ century (Lucier and VanStone 1992, Ponkratova 2006, Ray 1992, Spencer 1959 Zhushchikohovskaya 2005). 
Study of arctic ceramic technology is a newly expanding area of research in the north (Anderson and Brown 2007, Frink and Harry 2008, Harry and Frink 2009, Jordan and Zvelebil 2009, Miermon 2006, Ponkratova 2006, Zhushchikohovskaya 1997, 2005, Zhushchikohovskaya and Shubina 2006). Preliminary sourcing (Arnold and Stimmell 1983, Jozwik 2003, Lutz 1970, Stimmell 1994) and recent residue studies (Solazzo and Erhardt 2007, Solazzo et al. 2008) suggest the potential of ceramic studies in the Arctic. Undoubtedly, pottery played a vital role in northern hunter-gatherer economies and social lives (eg. Frink and Harry 2008, Jordan and Zvelebil 2009, Larsson 2009, Linton 1944, McKenzie 2009, Reid 1989), as it did elsewhere (Brown 1989, Crown and Wills 1995, Eerkens 2004, Hood 2007, Sampson 1988, Sassaman 1995). As in many parts of the world, pottery in the north is thought to have been made, used and exchanged primarily by women (Frink 2009, Pesonen and Leskinen 2009; but see Spencer 1959).

In general, ceramics in the North are considered by archaeologists to be an expedient technology with pots made quickly and poorly for short term use, particularly in the Neoeskimo period; this assumption is based in large part on the physical and technological characteristics of northern cooking pots (Jordan and Zvelebil 2009). These ideas about northern ceramics likely underlie the general lack of research involving ceramics in the region until recently. Indeed, if pots were only made and used in an expedient manner, it is unlikely that pottery was part of regional exchange systems. However, recent technological and experimental study of pottery from western coastal Alaska (Frink and Harry 2008, Harry and Frink 2009) has illustrated the technological expertise and planning required to make pots in this environment, suggesting that calling these pots "expedient" tools is misleading. This research seeks to build on this work by exploring the evidence for pre- $19^{\text {th }}$ century ceramic exchange networks.

\subsection{Environmental Context}

The timing of clay procurement and pottery production activities is limited to the short summer months (Frink and Harry 2008). Further constraints on pot production would have included access to pottery-making raw materials, specifically clay and fuel. Review of ethnographic data on clay procurement indicates that clay appropriate for pottery making was not widely available (de Laguna 1947, Giddings 1961, Lucier and VanStone 1992, Spencer 1959). Survey for potential clay sources on the Kobuk River and its tributaries carried out in summer 2010 supports this ethnographic evidence. Clay deposits on the Kobuk were limited in extent and unevenly distributed along the river system, which cross-cuts a large portion of the central part of the study area (Figure 1). People had knowledge of specific clay sources even after pottery was no longer made (eg. James 1990, Kugzruk 1987, Lee 1992, Noatak 1986), and in some cases, this knowledge was considered valuable or personal (Akagtak 1984). Ethnographic evidence suggests that people, at least in the $20^{\text {th }}$ century, had an appreciation for sources of "better" or higher-quality clay for making pots and lamps (Noatak and Kolerok 1987, Smith 1986). Access to these higher-quality clay sources was likely restricted to local groups as was the case for other limited resources with patchy distributions (Burch 2005, Kelly 1995). Pottery clay sources are reported at several locations on the Kobuk River, at Point Blossom on the Baldwin Peninsula, at Elephant Point near the Buckland River, and north of Cape Krusenstern (Anderson et al. 1998, Giddings 1952, Lucier and VanStone 1992). Variable clay quality and availability is not unexpected, given the highly varied bedrock geology and physiography of this region (Moore, et al. 1994, Patton Jr., et al. 1994, Till and Dumoulin 1994, see Figure 2). 
Fuel is typically the greatest cost in pottery production (Rice 1987, 1999), and there may be a link between fuel availability and ceramic "quality” in the Arctic (de Laguna 1947, Giddings 1952, but see Oswalt 1955).Reconstruction of past fuel availability is beyond the scope of the current study, but published data indicate variability in Late Holocene fuel supply across the region. Specifically, while fuel availability on the interior rivers was likely constant during the period in question (Mann and Hamilton 1995), driftwood availability and distribution on the coast was probably more variable (Alix 2005, Mason 2004).

\section{Hypotheses and Expectations}

The patchy distribution of critical pottery-making resources may be a key factor in the development of ceramic exchange systems and possibly, specialization. In general, social groups can control localized or heterogeneously distributed resources like clay or fuel sources, potentially expanding control through competition with other groups. Inequality can develop when some resource patches, or procurement technologies, are more productive than others. The groups that control multiple patches increase their power and buffer against risk of failure in any one resource patch. Furthermore, inter-group exchange minimizes risk in situations where resources are heterogeneously distributed; control of inter-group exchange is another avenue to increased rank (Kelly 1995). Limited access to the best clay raw material and fuel wood sources is expected, over time, to lead to expanded ceramic production and exchange in regions where the best clays and fuels were plentiful (Lucier and VanStone 1992).

If pottery production and use is local, limited to clay resources in the area around a given site, then high compositional difference between sites and low compositional diversity within sites is expected. If this hypothesis is rejected then alternative explanations for the observed compositional patterning can be considered. For example, it is possible that potters at different sites were either: 1) using geochemically similar raw materials; 2) pottery was part of a redistribution network; or 3) clay procurement took place as part of seasonal movements.

\section{MATERials AND Methods}

In order to test these expectations, large pottery collections are required from dated, multi-house settlements from across the environments and geological regions of northwest Alaska (Figures 1 and 2). Site areas selected for study include Cape Krusenstern , Kotzebue, Cape Espenberg , the Lopp Lagoon region , and several sites on the Kobuk River. The Kobuk River and Kotzebue collections were made by J.L. Giddings $(1952,1961)$ in the 1940s and 50s and by VanStone (1955) from house features at several sites locations. The within house context of these ceramics is unknown and it is probable that the collections are biased somewhat towards decorated sherds, rims and bases. The collections from the northern Seward Peninsula were made by the National Park Service (NPS) during survey and testing in the 1980s (Schaaf 1988) and limited excavation of several sites between 1988 and 1992 (Harritt 1994). Surface collection was non-systematic, with only diagnostic or unique sherds retained. All ceramic material, however, was collected during testing and excavation. The Cape Krusenstern collections were made as part of an on-going collaborative NPS-University of Washington research project at the Cape (Anderson and Freeburg 2009, 2010, Anderson et. al 2009). Older specimens were collected from surface scatters while younger specimens from various house and campsite locales were collected during site testing activities. Most of the sites and associated pottery 
assemblages date to the last 1000 years; older specimens are limited to the Cape Krusenstern beach ridge complex (Table 1). This study is focused on ceramic cooking pots andceramic lamps are excluded from this analysis.

To test predictions about local use versus longer distance exchange, pottery from each site was characterized through neutron activation analysis (NAA). The high precision, accuracy and sensitivity of NAA, as well as the ability to analyze small specimens are the primary reasons for selecting this method over other types of bulk chemical analysis (Neff 2002). Minimizing the impact of destructive analysis is particularly important in this case as the analytical sample comprises specimens from museum collections. Only a small portion, less than $0.5 \mathrm{~g}$, of each sherd is destroyed during NAA. The goal during selection of the NAA sample was to conduct analysis on only one sherd from each pot in each feature; rim sherds were therefore preferentially selected for analysis. Additionally, sherd physical properties (eg. temper type, color, texture) were taken into account when selecting specimens as these attributes may be indicative of the physical properties of different clay raw materials, a function of production techniques, and/or intended use.

Sources of chemical or mineralogical variation in pottery composition include the distribution of geological source materials, variability within geologic resources, clay and temper procurement practices, technological alteration of materials while making pottery pastes, and the use-life of the artifact. Determining clay sources from pottery is more difficult than sourcing lithic materials such as obsidian, because a clay source is not the result of a single depositional episode. Clay deposits are therefore not as discrete and typically do not have a homogenous internal composition (Neff 2000). However, sourcing is possible if the chemical or mineralogical differences between natural sources are greater than they are within each source. This is the provenance postulate as expressed by Weigand et al. (1977). Compositional studies conducted without sampling specific raw-material sources frequently rely on the criterion of abundance, which assumes that sources or pottery types are most abundant near their origin (Neff and Glowacki 2002). At a minimum, differences in ceramic/clay chemistry are expected between physiographic regions - north, central, and south — in northwest Alaska, primarily because of differences in bedrock geology (Figure 2).

Ceramic samples were prepared for NAA using procedures established at the Archaeometry Laboratory (Glascock 1992, Glascock and Neff 2003, Neff 2000). Neutron activation analysis of ceramics at MURR, which consists of two irradiations and a total of three gamma counts, constitutes a superset of the procedures used at most other NAA laboratories. Analyses at MURR typically produce elemental concentration values for 33 elements. Values for $\mathrm{Ni}$ were at or below detection limits in greater than $50 \%$ of the total sample $(\mathrm{n}=50)$, therefore $\mathrm{Ni}$ was excluded from consideration in the statistical treatment of these data.

Statistical analyses were subsequently carried out on base-10 logarithms of concentrations on the remaining 32 elements. Use of log concentrations rather than raw data compensates for differences in magnitude between the major elements, such as sodium, and trace elements, such as the rare earth elements (REEs). Transformation to base-10 logarithms also yields a more normal distribution for many trace elements. Principal component analysis (PCA), one of several commonly pattern recognition techniques typically applied to archaeological geochemical data (Glascock 1992, Neff 2000, 2002), was used here to analyze the results of 
NAA. The main goal of data analysis is to identify distinct homogeneous groups within the analytical database. The first principal component shows strong negative loading on a variety of transition metals (e.g., Cr, Co, V, Ti, Fe, and Sc), and strong positive loading on Ta, Cs, and Rb. The second principal component shows strong positive loading on a suite of REEs, and negative loading on alkali and alkali earth metals (e.g., Na, Ca, and Sr; see Figure 3). More than 90\% of the total chemical variation in the sample data set is explained by six principal components (PCs). Scores on these six PCs were used to formulate initial hypotheses concerning group structure in these data. Once initial groups were created, they were evaluated and refined using cluster analyses and bivariate plots of elemental concentrations. The compositional groups defined here have too few members to calculate Mahalanobis-distance-based probabilities using elemental concentrations. As such, we calculated these probabilities using scores on the first six principal components which, as stated previously, account for more than $90 \%$ of the cumulative variation in this dataset.

\section{RESULTS}

A total of 99 ceramic specimens were subjected to NAA (Table 1). Although the sample size is small, it is possible through PCA to identify three compositional macrogroups that are distinguished from each other based on concentrations of Ta, alkali metals (K, Rb, and Cs), and REEs (Dy, Yb, and Lu, see Figure 4 and 5).

Macrogroup 1 is distinguished by relative enrichment of various elements, including heavy REEs, K, and Ta. These samples are also slightly depleted in $\mathrm{Zr}$, Sr, and Fe relative to the rest of the sample. The majority (64\%) of the 28 specimens in this group are from southern Kotzebue Sound sites of Cape Espenberg $(n=6)$ and Lopp Lagoon $(n=12)$, suggesting that this macrogroup may be geographically associated with the southern Sound. It may be possible to subdivide Macrogroup 1 into at least two subgroups based on REE concentrations - nine specimens show slightly higher concentrations of REEs than the remaining 19 specimens in Macrogroup 1. However, given the overall small size of Macrogroup 1, and of these two potential subgroups, we cannot evaluate this proposition with any statistical rigor. Additional analyses of pottery from the region should aid in evaluating any distinctions within Macrogroup 1 .

Macrogroup 2 contains the average concentrations of most elements relative to the ceramic dataset from this region. The Ahteut (28\%) and Kotzebue (26\%) sites are represented strongly in Macrogroup 2, as are samples from the other Northern Kotzebue sites. In addition, three possible subgroups within Macrogroup 2 were identified, based primarily on variations in transition metals (Sc, Ti, V, and $\mathrm{Cr}$, see Figure 6). These potential subgroups suggest regional patterning in the chemical composition of ceramic fabrics, but sample sizes are currently too small for rigorous statistical analysis of this hypothesis. Subgroup 2a contains more than half of the Ahteut specimens, while Subgroup 2b contains nearly half of the Kotzebue sample. Subgroup 2c contains half of the Ekseavik specimens. Analysis of additional specimens may reveal more subgroups of which the unassigned Macrogroup 2 samples belong. Or, these currently unassigned pieces may belong to the subgroups identified in this analysis; but because of the small sample sizes we have not recognized the full range of variation in ceramic composition within the existing subgroups. 
Macrogroup 3 includes only three specimens, which are distinguished from the rest of the dataset by their depletion in REEs, K, Sb, Hf, and Ta. Slight variations in elemental composition suggest that two of these, SLA024 and SL025 from the Ambler Island site, are more similar to one another than the third specimen, SLA067 from Cape Krusenstern. Future analyses may result in the division of this macrogroup into two subgroups, but the sample size is currently too small to do so.

\section{DISCUSSION}

Several conclusions can be drawn from these data. First, it appears that there is a geographic distribution of the three macrogroups identified through NAA, with clear north to south differences in macrogroup distribution (Figure 7). Second, from this it can be concluded that the clays and tempers of this region adhere to the provenance postulate, meaning that there are distinct differences in the elemental composition of raw materials used to make pottery across these region, and that these differences can be used to address questions about rawmaterial procurement, pottery distribution, and ultimately, social organization and change. Third, ceramics from some sites, particularly Ahteut, Ekseavik, and Kotzebue, crosscut the macrogroups and subgroups defined here, further suggesting that people at a given site were using more than one source for their clay raw materials. It is reasonable to conclude from this that people wereprocuring clays as part of their seasonal round and/or that pots were part of regional exchange networks (Table 2).A third possibility is that finished ceramics were moving with women, independent of exchange networks.

Differentiating the movement of materials through trade or exchange from the movement of people with their materials is difficult in archaeological contexts. If people were highly mobile during the summer months, when pottery procurement was most likely, then the pattern seen here could be explained as the result of direct procurement of clays by highly mobile groups. However, the overall trend over time in this region is towards increased sedentism over the last 3000 years, as is evident in the increased size of houses and settlements as well as the range of activities represented at these sites. At the same time, it is also clear at a regional level that there was a dispersion of people away from most of the large coastal sites around 500 years ago as described in Section 2.1. The sample analyzed here is primarily from sites dating to the last 700 years (Table 1), spanning this period of changing settlement patterns. The sites included in this study, however, are primarily semi-permanent to permanent multi-family occupation sites (Anderson and Freeburg 2009, 2010, Giddings 1952, Giddings and Anderson 1986, Harritt 1994, Schaaf 1988), and the distribution of sourcing likely represents movement of pottery via exchange networks. Additional sampling with an expanded temporal scope would allow a rigorous testing of this hypothesis.

While clear north to south differences in source-group composition are apparent, there is little difference in the diversity of ceramic sources at coastal versus inland sites included in this study. Historically, coastal locations tended to be at or near trade centers, with annual trade fairs held at Sisualik and Wales, on the western tip of the Seward Peninsula (Burch 2005). River and interior dwellers would travel downstream to trade goods at the regional fair, either on the open market or with established trading partners. Specialized traders brought goods between people on the Upper Kobuk and Selawik Rivers to the coast (Burch 2006). If this was the case 
prehistorically, greater source diversity in the coastal sites at Krusenstern, Kotzebue, Cape Espenerg, and Lopp Lagoon would be expected in comparison to sites on the Kobuk River.

Preliminary stylistic study, however, reveals some interesting regional patterns. Considering just a few of the variables measured in the rim sherds, clear trends emerge in the decorative data. Like the compositional groups, there are clear north to south differences in pottery decorative styles and also variability in diversity of pottery styles across the sites. Ceramics are predominantly undecorated, but variability does exist in decorative types, with curvilinear and linear stamping more common in the central and northern areas of the study region, and striated decorations more common in the southern region (Table 3). Other attributes such as rim type, rim decoration, thickness, overall size and shape, were also considered, but larger sample sizes are needed, particularly from the northern and southern sites, before these data will be meaningful. Greater decorative diversity correlates with greater compositional group diversity at the Kotzebue and Ekseavik sites, further hinting at patterns of regional interaction (Figures 8 and 9). Sample size, however, is likely influencing the patterns seen here to some extent given that the sites with smaller sample sizes have lower source diversity.

With only a few specimens dating to more than 2000 years ago, this study lacks the temporal depth and sample size needed to address larger questions about changing territoriality and exchange networks over time. It is possible, however, to build on this successful pilot study and consider how ceramic source use and stylistic data could be used to explore the evidence for increasing territoriality and reliance on exchange networks in the context of modeling emerging social inequality in the north.

As territoriality increases in response to increasing population density and abundant, but variable, mid-to-late Holocene resources, a concurrent shift in ceramic source diversity can be expected. As groups become more territorial and competitive, local territories and the resources contained within them are expected to become more defined and protect. As resource access becomes more circumscribed, certain family groups in better positions with regard to rawmaterial access and trade or exchange partnerships will be able to monopolize trade in certain commodities, such as pottery, elevating their relative social standings and encouraging sustained competition over exchange partners and raw-material sources. A decrease in the diversity of sources used within a group over time and more difference between groups is expected as territorial groups establish control over certain areas and resources.

Increased diversity, greater definition of social identity and regionalization in artifact types, including ceramic styles (see Sampson 1988, Wiessner 1983, Wobst 1977), are expected as territoriality becomes more pronounced;O’Leary (1999) identified evidence for local decorative attributes that correlate with local linguistic groups on the Yukon-Kuskokwim delta, south of the current study area. Additional stylistic analysis of ceramics from northwest Alaska may identify localized types and wares, including pots made specifically for trade. If territoriality becomes more pronounced as population densities increase, greater definition of social identity or regionalization expressed in the material culture is expected - especially in pottery styles and diversity of styles. Local specialization may develop, at least in some locations where access to raw materials, such as high quality clay or fuel, was possible. If this occurs, a strong correlation between source use and ceramic styles is expected. Greater 
localization in the production of utilitarian objects, for example more exclusive use of local, even inferior, clays to avoid having to travel into other territories for better sources is expected with increased territoriality.

In addition to expanding the ceramic sample size, the inclusion of clay source samples from known (see Section 2.3) and possible locations in future analysis will allow us to link ceramic reference groups identified during sourcing to geographic locations, facilitating study of exchange networks. Source provenance survey would provide data on the availability and distribution clay resources in the study area, important for further assessing questions about exchange, territoriality and changing social organization.

\section{CONCLUSions}

Ceramic data provide a new line of evidence for addressing long-standing questions about exchange, territoriality and the emergence of complex social organization in the Arctic. Chemical analysis of ceramics from eight coastal and inland archaeological sites identified three source macrogroups and three subgroups within one of the macrogroups. Additional subgroups are suggested by these data, but at present the sample size is too small to rigorously evaluate their significance. Source diversity, and shared source macrogroups between geographically disparate site areas suggests the use of multiple sources and/or the movement of pots between production locales. Preliminary trends in stylistic data are present as well. These results confirm that ceramic source and distribution data are appropriate for testing a model of social change in northwest Alaska, and hint at interesting regional patterns of ceramic production and distribution. This preliminary sourcing study provides a basis for examining control and use of clay resources, the development of exchange systems, and possibly, specialized trade wares, as an index of developing social inequality. The incorporation of additional sites and samples in an expanded study, along with source provenance survey, will strengthen the explanatory power of this ceramic dataset.

\section{ACKNOWLEDGEMENTS}

Thank you to Eileen Devinney, Bob Gal, Robin Mills, Ken Pratt, Jeff Rasic, and Jim Whitney for invaluable advice as well as archives and collections access. Erik Gjesfjeld, Owen Mason and Amanda Taylor provided comments on an earlier draft of this article, which was also greatly improved by the comments of three anonymous reviewersDan Salberg and Corinne Rosania were responsible for preparation and irradiation of samples for this project. This study was funded by a University of Alaska Museum - Bureau of Land Management Collections Research Fellowship, a University of Washington Department of Anthropology Pre-dissertation Grant, and by NSF grant BCS-0802757 to the Archaeometry Laboratory of the Research Reactor, University of Missouri (MURR). The data generated in this study are available through the MURR Web site (http://archaeometry.missouri.edu/) or through request to the authors.

\section{REFERENCES CiTED}

Akagtak, T. 1984 Taped interview. Steven Street, interviewer; Cecilia Fairbanks, interpreter. June 21. Toksook Bay, Alaska. Tapes 84BAY005-006. BIA ANCSA Office, Anchorage. 
Alix, C., 2005. Deciphering the impact of change on the driftwood cycle: Contribution to the study of human use of wood in the Arctic, Global and Planetary Change 47, 83-98.

Ames, K. and H.Maschner,., 1999. Peoples of the Northwest Coast: Their archaeology and prehistory, Thames and Hudson, London.

Anderson, D.D., 1977. Prehistoric and early historic human settlements and resource use Areas in the Selawik Drainage, Alaska, Report to the U.S. National Park Service.

Anderson, D.D., 1984. Prehistory of North Alaska, in: Damas, D. (Ed.), Arctic, Smithsonian Institution press, Washington D.C., pp. 80-93.

Anderson, D.D., 1988. Onion Portage: The archaeology of a stratified site from the Kobuk River, Northwest Alaska, Anthropological Papers of the University of Alaska 22.

Anderson, D.D., Anderson, W.W., Bane, R., Nelson, R.K., Towarak, N.S., 1998. Kuuvanmiut subsistence: traditional Eskimo life in the latter Twentieth Century, U.S. Dept. of the Interior, National Park Service, Washington, D.C.

Anderson, S., Brown, W., 2007. Analysis of ceramics from the Kukulik Site, St. Lawrence Island, Report prepared for the University of Alaska Museum.

Anderson, S., Freeburg, A., 2009. Human and environmental dynamics at Cape Krusenstern National Monument, two hundred generations: on the beach of their time, Interim archaeological report, National Park Service, Anchorage, AK.

Anderson, S. and A. Freeburg 2010. Human and environmental dynamics at Cape Krusenstern National Monument, Two Hundred Generations: On the Beach of Their Time, Interim archaeological report. Anchorage, National Park Service.

Anderson, S., A. Freeburg, and B. Fitzhugh 2009. Cultural vulnerability and resilience in the Arctic: Preliminary report on archaeological fieldwork at Cape Krusenstern, Northwest Alaska. Alaska Park Science, Park Science Conference Proceedings. Alaska Park Science 8(2): 41-45. Arnold, C.D. and C.Stimmell,, 1983. An analysis of Thule pottery, Canadian Journal of Archaeology 7, 1-21.

Arnold, J. E. 1993 Labor and the rise of complex hunter-gatherers. Journal of Anthropological Archaeology 12:75-119.

1996a The archaeology of complex hunter-gatherers. Journal of Method and Theory 3:77-126. 1996b. Organizational transformations: power and labor among complex hunter-gatherers and other intermediate societies, in: Arnold, J.E. (Ed.), Emergent complexity: the evolution of intermediate societies, International Monographs in Prehistory, Ann Arbor, Mich., pp. 59-73.

Binford, L. R. 1980 Willow Smoke and Dog's Tails: Hunter-Gatherer Settlement Systems and Archaeological Site Formation. American Antiquity 45(1):4-20. 
2001 Constructing Frames of Reference. University of California Press, Berkeley.

Brigham-Grette, J., Lozhkin, A.V., Anderson, P.M., Glushkova, O.Y., 2004. Paleoenvironmental conditions in western Beringia before and during the Last Glacial Maximum, in: Madsen, D.B. (Ed.), Entering America: Northeast Asia and Beringia before the Last Glacial Maximum, University of Utah Press, Salt Lake City, pp. 29-61.

Brown, J.A., 1989. The beginnings of pottery as an economic process, in: van der Leeuw, S.E., Torrence, R. (Eds.), What's new? A closer look at the process of innovation, Unwin Hyman, London, pp. 203-224.

Burch, E.S.J., 1998. The Inupiaq Eskimo Nations of Northwest Alaska, University of Alaska Press, Fairbanks.

Burch, E.S.J., 2005. Alliance and conflict: the world system of the Inupiaq Eskimos, University of Nebraska Press, Lincoln.

Burch, E.S.J., 2006. Social life in Northwest Alaska: the structure of Inupiaq Eskimo nations, University of Alaska Press, Fairbanks.

Clark, D.W., 1984. Prehistory of the Pacific Eskimo Region, in: Damas, D. (Ed.), Arctic, Smithsonian Institution, Washington, pp. 136-148.

Crown, P.L., Wills, W.H., 1995. Economic intensification and the origins of ceramic containers in the American Southwest, in: Barnett, W.K., Hoopes, J.W. (Eds.), The emergence of pottery: technology and innovation in ancient societies, Smithsonian Institution Press, Washington, pp. 241-254.

De Laguna, Frederica. 1947. The prehistory of northern North America as seen from the Yukon. Menasha, Wis: Society for American Archaeology.

Dumond, D.E., 1977. The Eskimos and Aleuts, Thames and Hudson Ltd, London.

Dumond, D.E., 1984. Prehistory of the Bering Sea Region, in: Damas, D. (Ed.), Arctic, Smithsonian Institution Press, Washington., pp. 94-105.

Eerkens, J.W., 2004. Privatization, small-seed intensification, and the origins of pottery in the Great Basin, American Antiquity 69, 653-670.

Erlandson, J.M., Moss, M.L., Des Lauriers, M., 2008. Life on the edge: early maritime cultures of the Pacific Coast of North America, Quaternary Science Reviews 27, 2232-2245.

Feinman, G.M., 1995. The emergence of inequality: a focus on strategies and processes, in: Price, T.D., Feinman, G.M. (Eds.), Foundations of social inequality, Plenum Press, New York, pp. 255-279. 
Fitzhugh, B. 2003 The evolution of complex hunter-gatherers: archaeological evidence from the North Pacific. Interdisciplinary Contributions to Archaeology. Kluwer Academic/Plenum Publishers, New York.

Friesen, T.M., 2007. Hearth rows, hierarchies and Arctic hunter-gatherers: the construction of equality in the Late Dorset period, World Archaeology 39, 194-214.

Frink, L., and K. Harry, 2008. The beauty of "ugly" Eskimo cooking pots, American Antiquity 73, 103-118.

Frink, L., 2009. The identity division of labor in Native Alaska, American Anthropologist 111, 21-29.

Giddings, J.L., 1952. The Arctic Woodland culture of the Kobuk River, University of Pennsylvania, Museum Monographs 8.

Giddings, J.L., 1961. Kobuk River People, Studies of Northern Peoples 1.

Giddings, J.L., Anderson, D.D., 1986. Beach Ridge Archeology of Cape Krusenstern: Eskimo and Pre-Eskimo Settlements Around Kotzebue Sound, Alaska., National Park Service, Washington, D.C.

Glascock, M.D., 1992. Characterization of archaeological ceramics at MURR by neutron activation analysis and multivariate statistics, in: Neff, H. (Ed.), Chemical characterization of ceramic pastes in archaeology, Prehistory Press, Madison.

Glascock, M.D., Neff, H., 2003. Neutron activation analysis and provenance research in archaeology, Measurement Science and Technology 14, 1516-1526.

Hall, E.S., 1971. Kangiguksuk: A cultural reconstruction of a sixteenth century Eskimo site in Northern Alaska, Arctic Anthropology 8, 1-101.

Hall, E.S., 1976. A preliminary analysis of house types at Tukuto Lake, Northern Alaska, in: Hall Jr., E.S. (Ed.), Contributions to Anthropology: The Interior Peoples of Northern Alaska, Canadian Museum of Civilization, Archaeological Survey of Canada, Ottawa, pp. 98-134.

Harritt, R.K., 1994. Eskimo Prehistory on the Seward Peninsula, in: U.S. National Park Service, A.R.R.R.N.A.C.-. (Ed.).

Harry, K., Frink, L., 2009. The arctic cooking pot: Why was it adopted?, American Anthropologist 111, 330-343.

Hayden, B. 1994 Competition, labor, and complex hunter-gatherers. In Key Issues in HunterGatherer Research, edited by E. S. Burch and L. J. Ellana, pp. 223-239. Berg Press, Oxford. 
Hayden, B., 1995. Pathways to power: principles for creating socio-economic inequalities, in: Price, J., Feinman, G.M. (Eds.), Foundations of social inequality, Plenum Press, New York, pp. 15-86.

Hickey, C.G., 1968. The Kayák Site: an analysis of the spatial aspect of culture as an aid to archaeological inference., Department of Sociology and Anthropology, Brown University, Providence.

1977. Process in prehistory: a structural analysis of change in an Eskimo culture, Department of Anthropology, Brown University, Providence.

Hood, L. N. (2007). Modeling hunter-gatherer ceramic production and use : a test case from the upper Texas coastal plain. PhD Dissertation, University of Washington, Seattle.

Irving, W.N., 1962. 1961 Field Work in the Western Brooks Range, Alaska: Preliminary Report, Arctic Anthropology 1, 76-83.

James, J. 1990 Taped interview. Marie Meade and Mary Ellen Fogarty, interviewers; Marie Meade, interpreter. June 28. Goodnews Bay, Alaska. Tape 90PLA019. BIA ANCSA Office, Anchorage.

Jordan, P. and M. Zvelebil (2009). Ex oriente lux: the prehistory of hunter-gatherer ceramic dispersals. In: Ceramics before farming: the dispersal of pottery among prehistoric Eurasian hunter-gatherers. P. Jordan and M. Zvelebil. Walnut Creed, Left Coast Press, Inc.: 33-89.

Jozwik, D., 2003. Sourcing clay sediments used in pottery production at Kukulik, Saint Lawrence Island, Alaska. Geological Society of America, Seattle.

Kelly, R.L., 1995. The foraging spectrum, Smithsonian Institution Press, Washington D.C.

2000 Elements of a Behavioral Ecological Paradigm for the Study of Prehistoric HunterGatherers. In Social Theory in Archaeology, edited by M. B. Schiffer, pp. 63-78. University of Utah Press, Salt Lake City.

Kennett, D. J. 2005. The island Chumash: behavioral ecology of a maritime society. University of California Press, Berkeley.

Kugzruk, E 1987 Taped interview. Robert Waterworth, interviewer; Morris Kugzruk, interpreter. July 20. Teller, Alaska. Tapes 87TEL009-010. BIA ANCSA Office, Anchorage.

Larsson, M. (2009). The pitted ware culture in eastern middle Sweden: Material Culture and Human Agency. In: Ceramics before farming: the dispersal of pottery among prehistoric Eurasian hunter-gatherers. P. Jordan and M. Zvelebil. Walnut Creek, Left Coast Press, Inc.: 395-419. 
Lee, C. 1992 Lore of the Inupiat: The Elders Speak, Volume III. Linda Piquk Lee, Ruthie Tatqavin Sampson and Edward Tennant, editors. Northwest Arctic Borough School District, Kotzebue.

Linton, R., 1944. North American cooking pots, American Antiquity 9, 369-380.

Lucier, C.V., VanStone, J.W., 1992. Historic pottery of the Kotzebue Sound Inupiat, Anthropology New Series, No. 18.

Lutz, B., 1970. Variations in checked pottery from an archaeological site Near Unalakleet, Alaska Anthropological Papers of the University of Alaska 15.

McKenzie, H. G. (2009). Review of early hunter-gatherer pottery in Eastern Siberia. In: Ceramics before farming: the dispersal of pottery among prehistoric Eurasian hunter-gatherers. P. Jordan and M. Zvelebil. Walnut Creek, Left Coast Press, Inc.: 167-208.

Mann, D.H., Hamilton, T.D., 1995. Late Pleistocene and Holocene paleoenvironments of the North Pacific Coast, Quaternary Science Reviews 14, 449-471.

Mason, O.K., Gerlach, S.C., 1995a. Chukchi Sea hot spots, paleo-polynyas and caribou crashes: climatic and ecological constraints on Northern Alaska prehistory, Arctic Anthropology 32, 101130.

Mason, O.K., Gerlach, S.C., 1995b. The archaeological imagination, zooarchaeological data, the origins of whaling in the Western Arctic, and "Old Whaling" and Choris Cultures, in: McCartney, A.P. (Ed.), Hunting the Largest Animals, The Canadian Circumpolar Institute, Calgary, pp. 1-31.

Mason, O.K., 1998. The contest between the Ipiutak, Old Bering Sea, and Birnirk polities and the origin of whaling during the first millenium A.D. along Bering Strait, Journal of Anthropological Archaeology 17, 240-325.

Mason, O.K., Barber, V., 2003. A paleo-geographic preface to the origins of whaling: cold is better, in: McCartney, A.P. (Ed.), Indigenous Ways to the Present: Native Whaling in the Western Arctic, Canadian Circumpolar Institute (CCI) Press and the University of Utah Press, Edmonton and Salt Lake City, pp. 69-108.

Mason, O.K., 2004. Ipiutak remains mysterious: a focal place still out of focus., in: Arneborg, J., Grønnow, B., Greenland Research, C., North Atlantic Biocultural, O., Nationalmuseet (Eds.), Dynamics of northern societies: proceedings of the SILA/NABO Conference on Arctic and North Atlantic Archaeology, Copenhagen, May 10th-14th, 2004, National Museum of Denmark, Copenhagen, pp. 103-119.

Miermon, A.G., 2006. Pottery from the Ekven Bluf, in: Dumond, D.E., Bland, R.L. (Eds.), Archaeology in Northeast Asia: On the Pathway to Bering Strait, Museum of Natural and Cultural History and Department of Anthropology, University of Oregon, Eugene, pp. 159-189. 
Mochanov, I.A., Powers, R., 1969a. The Bel'kachinsk Neolithic culture on the Aldan, Arctic Anthropology 6, 104-114.

Mochanov, I.A., Powers, R., 1969b. The Ymyiakhtakh Late Neolithic culture, Arctic Anthropology 6, 115-118.

Moore, T.E., Wallace, W.K., Bird, K.J., Karl, S., M., Mull, C.G., Dillon, J.T., 1994. Geology of Northern Alaska, in: Plafker, G., Berg, H.C. (Eds.), The geology of Alaska, The Geological Society of America, Inc., Boulder, pp. 49-140.

Neff, H., 2000. Neutron activation analysis for provenance determination in archaeology, in: Ciliberto, E., Spoto, G. (Eds.), Modern analytical methods in art and archaeology, WileyInterscience, New York, pp. 81-134.

Neff, H., 2002. Quantitative techniques for analyzing ceramic compositional data, in: Glowacki, D.M., Neff, H. (Eds.), Ceramic production and circulation in the greater Southwest: source determination by INAA and complementary mineralogical investigations, The Cotsen Institute of Archaeology, University of California, Los Angeles, pp. 15-67.

Neff, H., Glowacki, D.M., 2002. Ceramic source determination by insturmental neturon activation analysis in the American Southwest, in: Glowacki, D.M., Neff, H. (Eds.), Ceramic production and circulation in the greater Southwest: source determination by INAA and complementary mineraological investigations, The Cotsen Institute of Archaeology, University of California, Los Angeles, pp. 1-14.

Nelson, E.W., 1983. The Eskimo about Bering Strait, Smithsonian Institution Press, Washington, D.C.

Noatak, A. 1986 Taped interview. Ken Pratt and Miriam Stark, interviewers; Howard Amos, interpreter. August 25. Mekoryuk, Alaska. Tape 86NUN061. BIA ANCSA Office, Anchorage.

Noatak, A. and R. Kolerok 1987 Taped interview. Robert Drozda, interviewer; Howard Amos, interpreter. November 5. Mekoryuk, Alaska. Tape 87NUN006. BIA ANCSA Office, Anchorage.

O’Leary, M. 1999 Early Yupiit-Cupiit regional groups with special reference to ceramic cooking pot designs. Paper presented at the $26^{\text {th }}$ Annual Alaska Anthropological Association meetings, March 31-April 3, Fairbanks.

Osgood, C., 1940. Ingalik material culture, Pub. for the Department of anthropology, Yale University, by the Yale University Press; H. Milford Oxford University Press, New Haven; London.

Oswalt, W., 1955. Alaskan pottery: a classification and historical reconstruction, American Antiquity 21, 32-43. 
Patton Jr., W., Box, S., Moll-Stalcup, E., Miller, T., 1994. Geology of West-Central Alaska, in: Plafker, G., Berg, H.C. (Eds.), The geology of Alaska, The Geological Society of America, Boulder, pp. 241-269.

Pesonen, P. and S. Leskinen 2009. Pottery of the Stone Age hunter-gatherers in Finland. In: Ceramics before Farming: the dispersal of pottery among prehistoric Eurasian huntergatherers. P. Jordan and M. Zvelebil. Walnut Creek, Left Coast Press, Inc.: 299-318.

Ponkratova, I., 2006. Pottery industries in the North of the Russian Far East, in: Dumond, D.E., Bland, R.L. (Eds.), Archaeology in Northeast Asia: on the pathway to Bering Strait, Museum of Natural and Cultural History and Department of Anthropology, University of Oregon, Eugene, pp. 129-158.

Price, T. D. and G. M. Feinman, eds 1995. Foundations of social inequality. New York, Plenum Press.

Ray, D.J., 1992. The Eskimos of Bering Strait, 1650-1898, University of Washington Press, Seattle.

Reid, K.C., 1989. A materials science perspective on hunter-gatherer pottery, in: Bronitsky, G. (Ed.), Pottery technology: ideas and approaches, Westview Press, London, pp. 167-180.

Rice, P.M., 1987. Pottery Analysis: A Sourcebook, The University of Chicago Press, Chicago and London.

1999. On the Origins of Pottery. Journal of Archaeological Method and Theory. 6(1): 154.

Sampson, C.G., 1988. Stylistic boundaries among mobile hunter-foragers, Smithsonian Institution Press, Washington.

Sassaman, K.E., 1995. The social contradictions of traditional and innovative cooking technologies in the prehistoric American Southeast, in: Barnett, W.K., Hoopes, J.W. (Eds.), The emergence of pottery: technology and innovation in ancient societies, Smithsonian Institution Press, Washington, pp. 223-254.

2004 Complex hunter-gatherers in evolution and history: a North American perspective. Journal of Archaeological Research, Vol. 12, No. 3, 227-280.

Savelle, J.M., Wenzel, G., 2003. Out of Alaska: reconstructing the social structure of prehistoric Canadian Thule culture, in: Habu, J., Savelle, J.M., Koyama, S., Hongo, H. (Eds.), Huntergatherers of the North Pacific Rim, National Museum of Ethnology, Osaka, pp. 103-121.

Schaaf, J., 1988. The Bering Land Bridge: an archaeological survey, National Park Service Resources Management Report, National Park Service, Anchorage. 
Sheehan, G.W., 1997. In the belly of the whale, Aurora, Alaska Anthropological Association Monograph Series, Anchorage.

Shirar, S., 2009. Subsistence and seasonality at a late prehistoric house pit in Northwest Alaska, Journal of Ecological Anthropology 13, 6-25.

Smith, P. 1986 Taped interview. Ken Pratt and Robert Drozda, interviewers. July 29. Mekoryuk, Alaska. Tape 86NUN036. BIA ANCSA Office, Anchorage.

Solazzo, C., Erhardt, D., 2007. Analysis of lipid residues in archaeological artifacts: marine mammal oil and cooking practices in the Arctic, in: Barnard, H., Eerkens, J.W. (Eds.), Theory and Practice of Archaeological Residue Analysis, Archaeopress, Oxford, pp. 161-178.

Solazzo, C., Fitzhugh, W.W., Rolando, C., Tokarski, C., 2008. Identification of protein remains in archaeological potsherds by proteomics, Analytical Chemistry 80, 4590-4597.

Spencer, R.F., 1959. The North Alaskan Eskimo : a study in ecology and society, U.S. Govt. Print. Off., Washington, DC.

Stanford, D.J., 1976. The Walakpa site, Alaska : its place in the Birnirk and Thule cultures, Smithsonian Institution Press : For sale by the Supt. of Docs., U.S. Govt. Print. Off., Washington.

Stefansson, V., Wissler, C., 1914. Stefánsson-Anderson Arctic expedition, American Museum of Natural History, New York.

Stimmell, C., 1994. Going to pot: a technological overview of North American Arctic ceramics, in: Morrison, D., Pilon, J.-L. (Eds.), Threads of Arctic prehistory: papers in honour of William E. Taylor Jr., Canadian Museum of Civilization, pp. 35-56.

Stoney, G.M., 1900. Naval explorations in Alaska; an account of two naval expeditions to northern Alaska, United States Naval Institute, Annapolis, Md.

Till, A.B., Dumoulin, J.A., 1994. Geology of Seward Peninsula and Saint Lawrence Island, in: Plafker, G., Berg, H.C. (Eds.), The geology of Alaska, Geological Society of America, Boulder, pp. 141-152.

VanStone, J.W., 1954. Pottery from Nunivak Island, Alaska, Anthropological Papers of the University of Alaska 2, 181-193.

1955 Archaeological Excavations at Kotzebue, Alaska. Anthropological Papers of the University of Alaska. 3(2). 
VanStone, J.W., Goddard, I., 1981. Territorial groups of West-Central Alaska before 1898, in: Helm, J. (Ed.), Handbook of North American Indians: Subarctic, Smithsonian Institution, Washington.

Weigand, P.C., Harbottle, G., Sayre, E.V., 1977. Turquoise sources and source analysis: Mesoamerican and the Southwestern USA, in: Earle, T.K., Ericson, J.E. (Eds.), Exchange systems in prehistory, Academic Press, New York, pp. 15-34.

Whitridge, P.J., 1999. The construction of social difference in a prehistoric Inuit whaling community, Anthropology, Arizona State University, Tucson.

Wiessner, P., 1983. Style and social Information in Kalahari San projectile points, American Antiquity 48, 253-276.

Wobst, H.M., 1977. Stylistic behavior and information exchange, in: Cleland (Ed.), For the Director: Research Essays in Honor of James B. Griffin, Museum of Anthropology, University of Michigan, Ann Arbor, pp. 317-342.

Yesner, D. R. 1998 Origins and Development of Maritime Adaptations in the Northwest Pacific Region of North America: A Zooarchaeological Perspective. Arctic anthropology. 35(1):204.

Zhushchikohovskaya, I.S., 1997. On early pottery-making in the Russian Far East, Asian Perspectives 36, 159-174.

Zhushchikohovskaya, I. S., 2005. Prehistoric pottery-making of the Russian Far East. BAR International Series. Oxford, Archaeopress. Edited and translated by Richerd Bland and C. Melvin Aikens.

Zhushchikohovskaya, I. S. 2009. Pottery making in prehistoric cultures of the Russian Far East. In: Ceramics before farming: the dispersal of pottery among prehistoric Eurasian huntergatherers. P. Jordan and M. Zvelebil. Walnut Creek, Left Coast Press, Inc.: 121-147.

Zhushchikohovskaya, I.S., Shubina, O.A., 2006. Pottery making and the culture history of Neolithic Sakhalin, in: Dumond, D.E., Bland, R.L. (Eds.), Archaeology in Northeast Asia: on the pathway to Bering Strait, Museum of Natural and Cultural History and Department of Anthropology, University of Oregon, Eugene, pp. 91-128. 


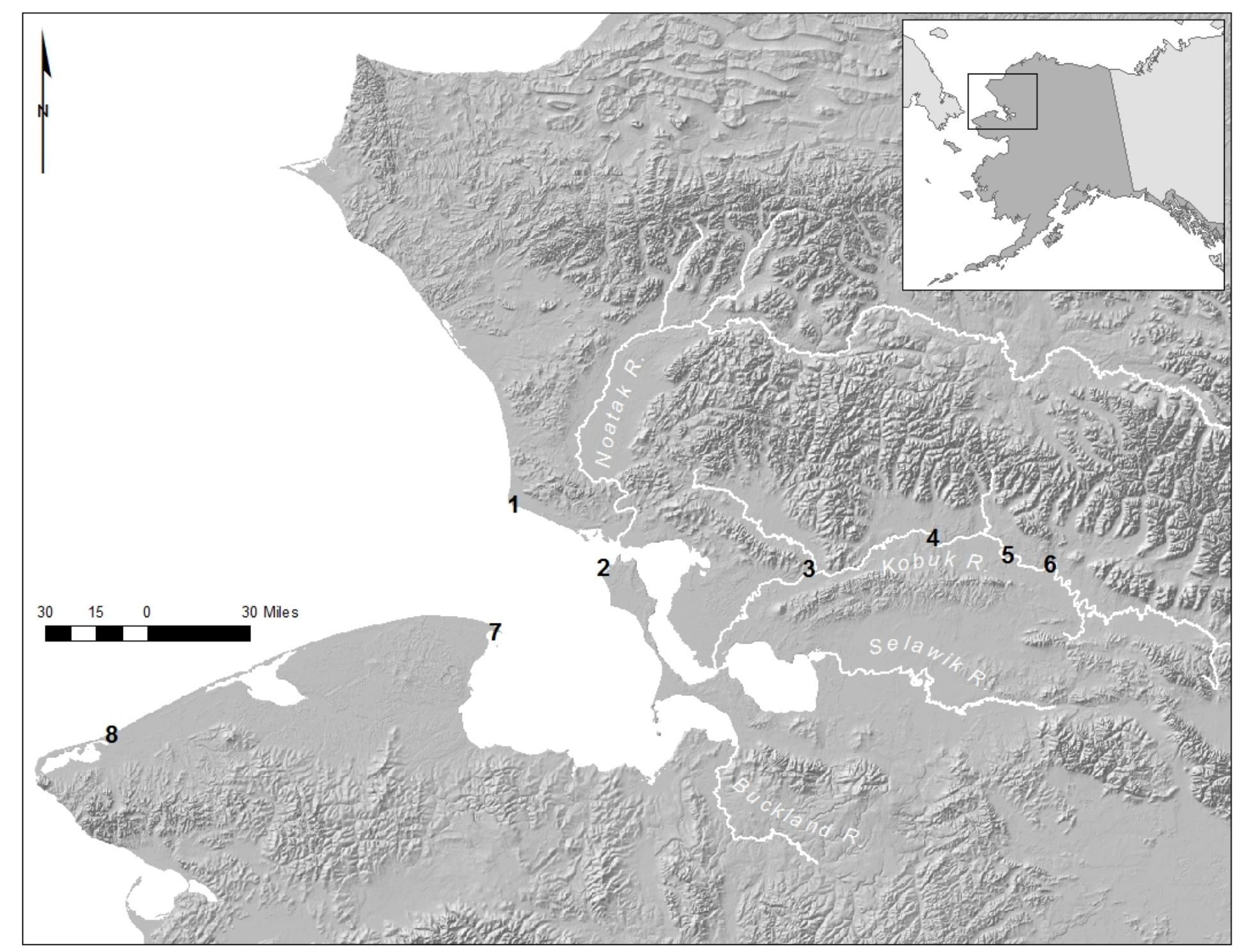

Figure 1. Project area with study site locations indicated: 1) Cape Krusenstern, 2) Kotzebue, 3) Ekseavik, 4) Ahteut, 5) Onion Portage, 6) Ambler Island, 7) Cape Espenberg, 8) Lopp Lagoon 


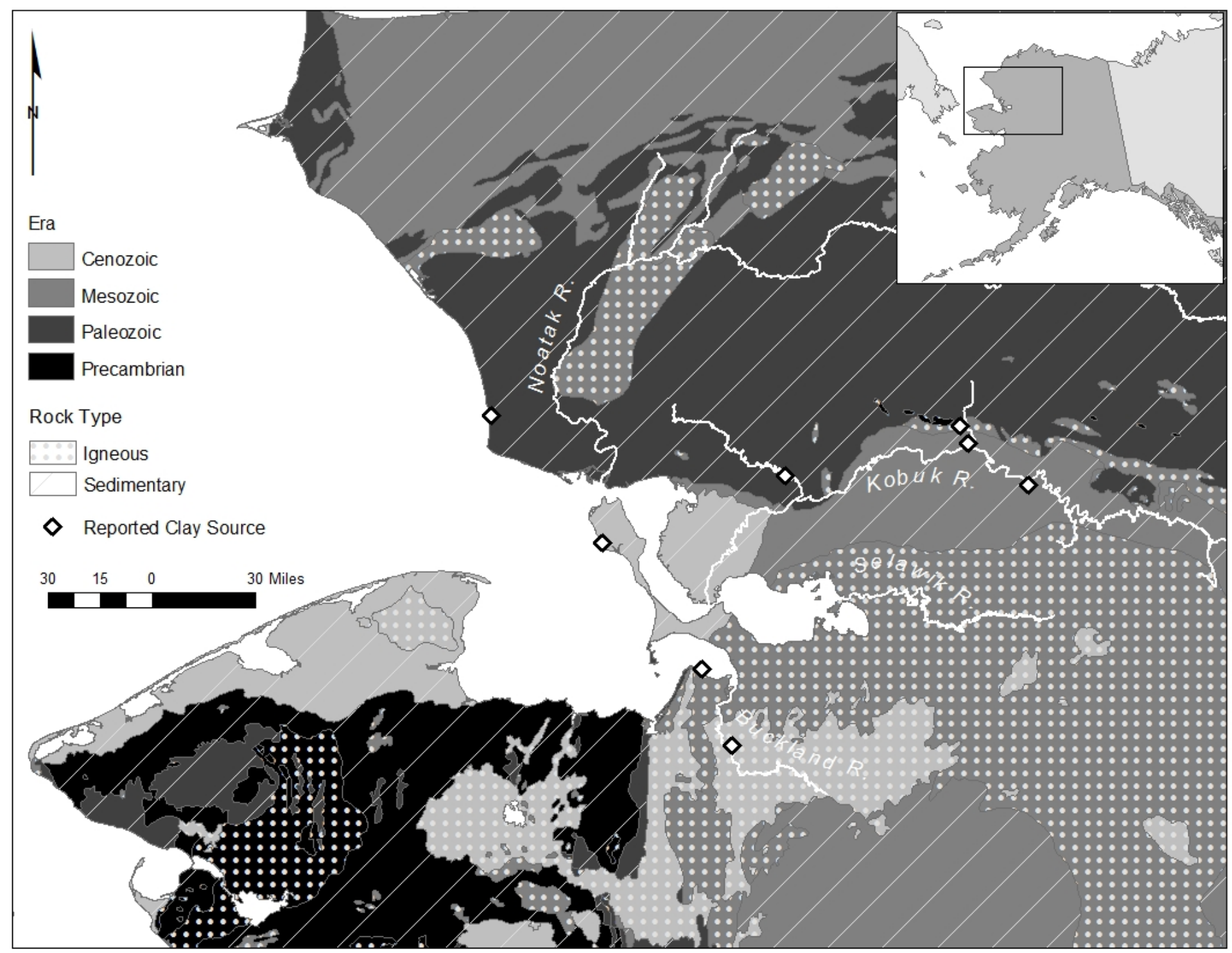

Figure 2. Bedrock geology map with reported clay sources indicated (Anderson, et al., 1998; Burch, 1998; Giddings, 1952, 1961; Lucier and VanStone, 1992; NANA, n.d.). 
Table 1. Archaeological sites in northwest Alaska included in this study

\begin{tabular}{|c|c|c|c|}
\hline Site Name & Approx. Date & Site Type & $\begin{array}{l}\text { Number of } \\
\text { Samples }\end{array}$ \\
\hline Ahteut & $750-700 \mathrm{cal} \mathrm{BP}$ & $\begin{array}{l}\text { Semi-Permanent/Permanent } \\
\text { Dwelling }\end{array}$ & 20 \\
\hline Ambler Island & 250-190 cal BP & $\begin{array}{c}\text { Semi-Permanent/Permanent } \\
\text { Dwelling }\end{array}$ & 6 \\
\hline Ekseavik & $550 \mathrm{cal} \mathrm{BP}$ & $\begin{array}{c}\text { Semi-Permanent/Permanent } \\
\text { Dwelling }\end{array}$ & 10 \\
\hline Kotzebue & 550-400 cal BP & $\begin{array}{c}\text { Semi-Permanent/Permanent } \\
\text { Dwelling }\end{array}$ & 23 \\
\hline Cape Espenberg & 700 cal BP-recent & $\begin{array}{c}\text { Semi-Permanent/Permanent } \\
\text { Dwelling }\end{array}$ & 8 \\
\hline Cape Krusenstern & 2900-2000 cal BP & Seasonal Campsite & 3 \\
\hline Cape Krusenstern & $\begin{array}{l}2000 \text { cal BP - } \\
\text { recent }\end{array}$ & $\begin{array}{c}\text { Semi-Permanent/Permanent } \\
\text { Dwelling }\end{array}$ & 11 \\
\hline Lopp Lagoon & 700-100 cal BP & $\begin{array}{c}\text { Semi-Permanent/Permanent } \\
\text { Dwelling }\end{array}$ & 12 \\
\hline Onion Portage & 550 cal BP & $\begin{array}{c}\text { Semi-Permanent/Permanent } \\
\text { Dwelling }\end{array}$ & 6 \\
\hline
\end{tabular}




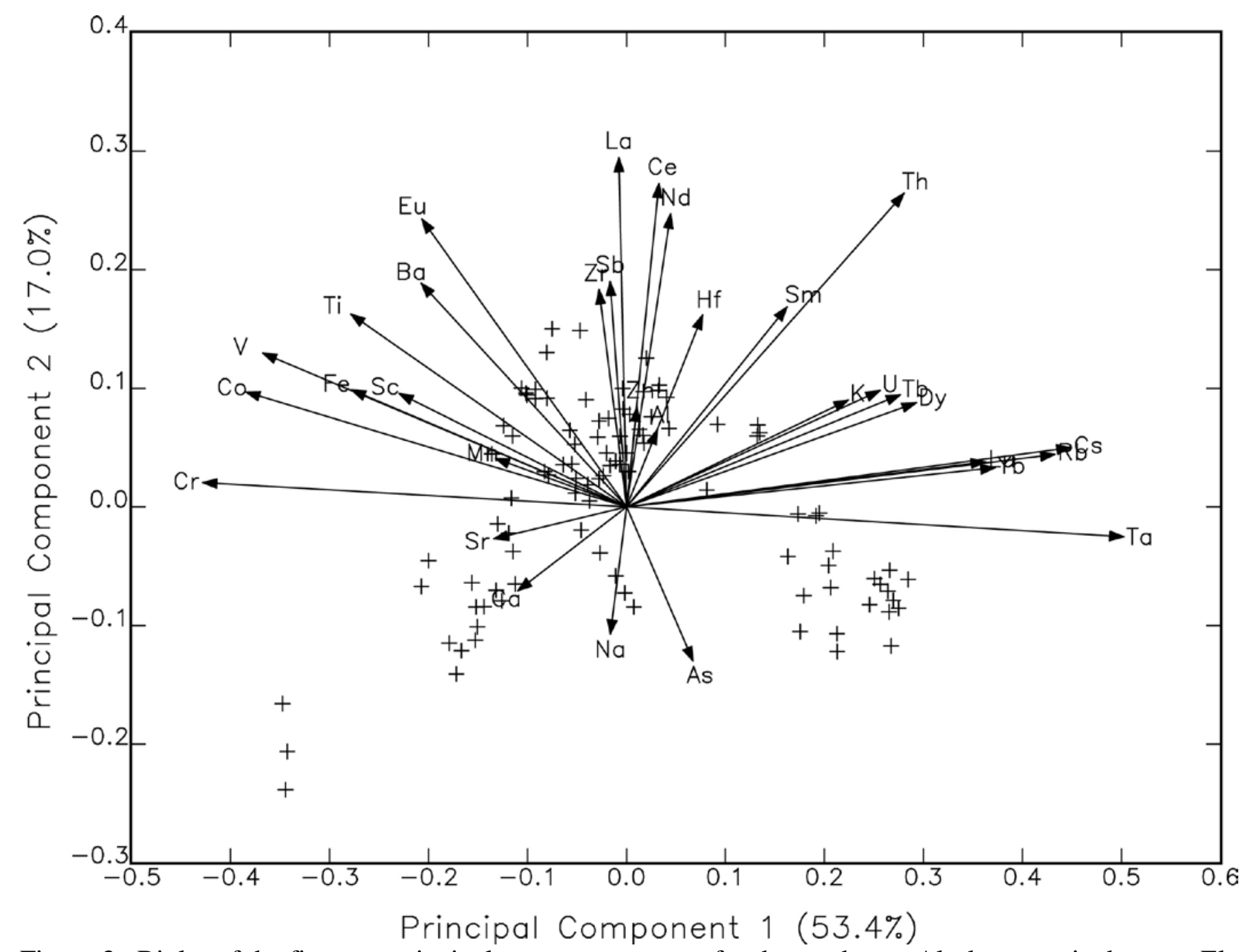

Figure 3. Biplot of the first two principal component scores for the northwest Alaska ceramic dataset. Elemental loading axes are shown and labeled. This biplot describes $70.4 \%$ of the cumulative variation in the dataset. 


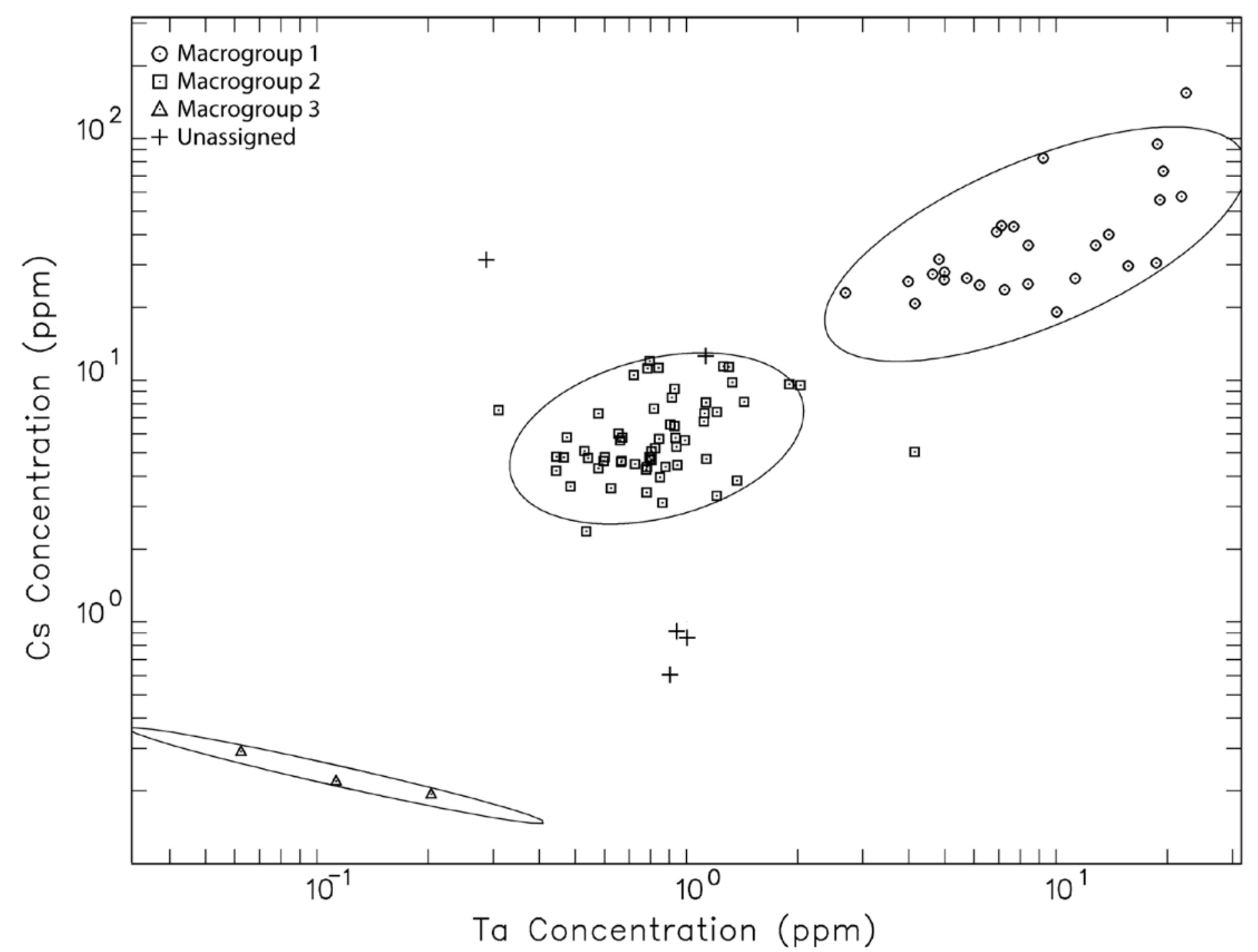

Figure 4. Bivariate log-log plot of tantalum (Ta) and cesium (Cs) concentrations showing the three macrogroups identified in this study. Ellipses represent $90 \%$ confidence interval of group membership. 


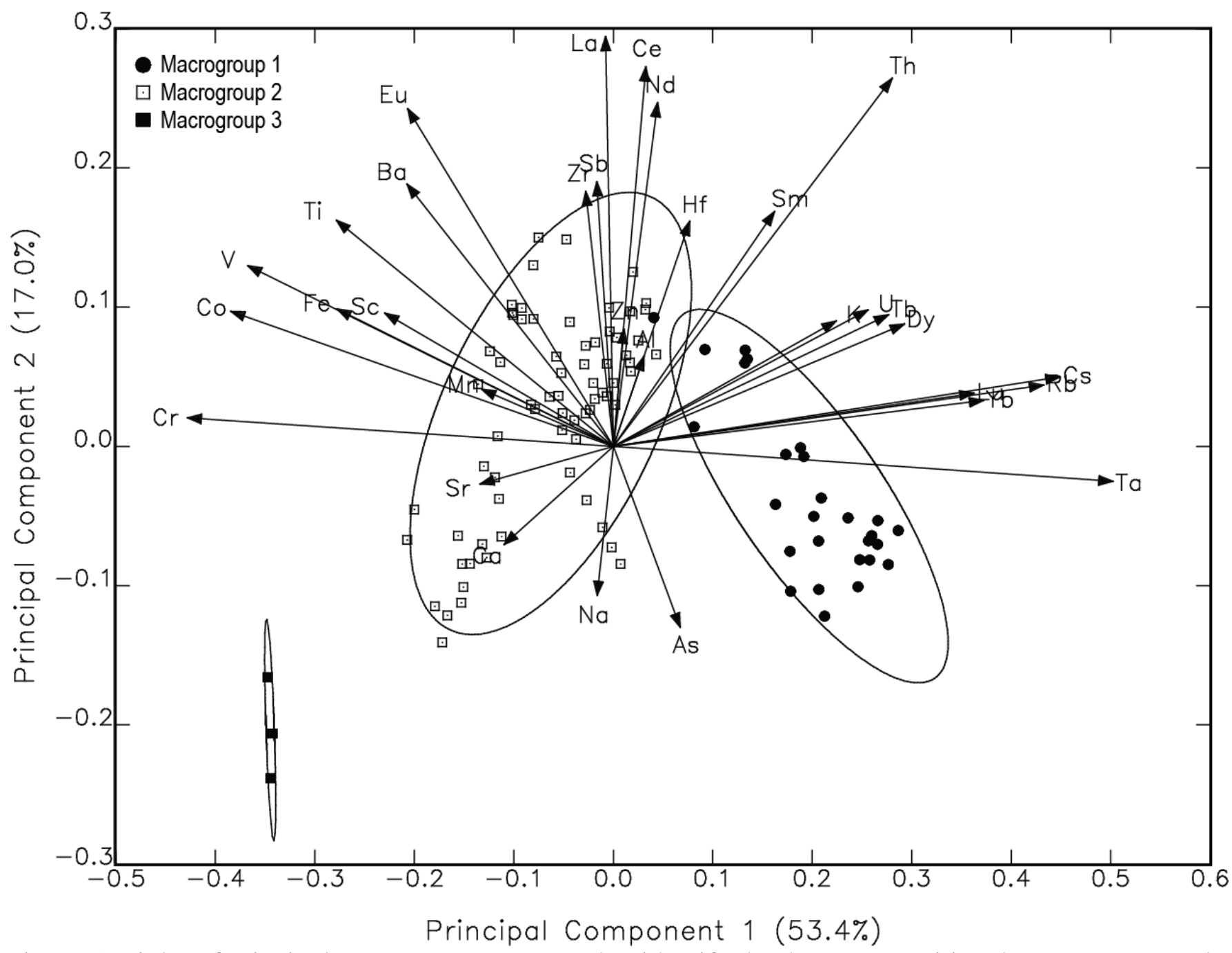

Figure 5. Biplot of principal component scores used to identify the three compositional macrogroups. Elemental loading axes are shown and labeled. Ellipses are drawn at the $90 \%$ confidence interval. 


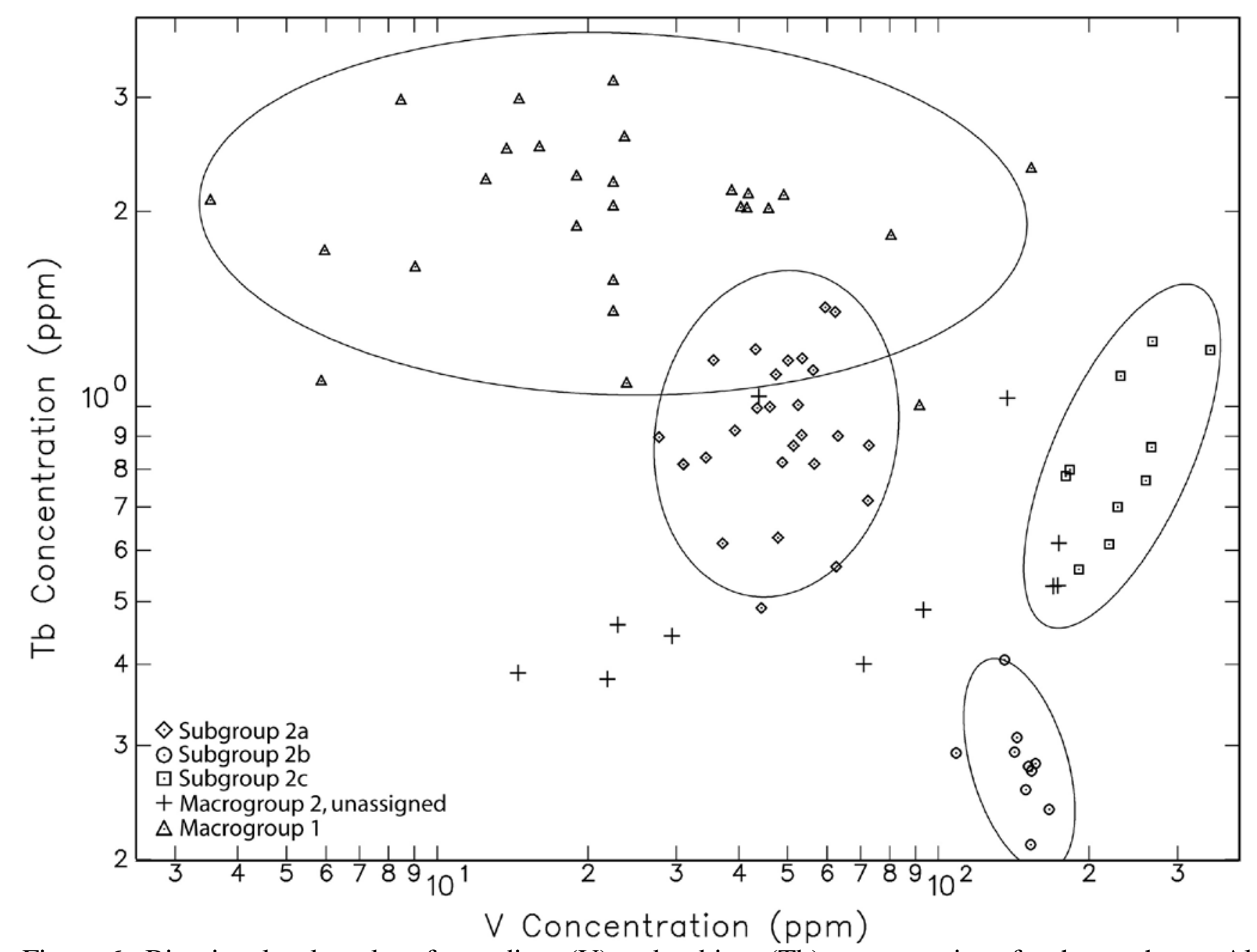

Figure 6. Bivariate log-log plot of vanadium (V) and terbium (Tb) concentrations for the northwest Alaska ceramic dataset. Macrogroup 1 and subgroups of Macrogroup 2 are shown. Ellipses represent 90\% confidence interval of group membership. 


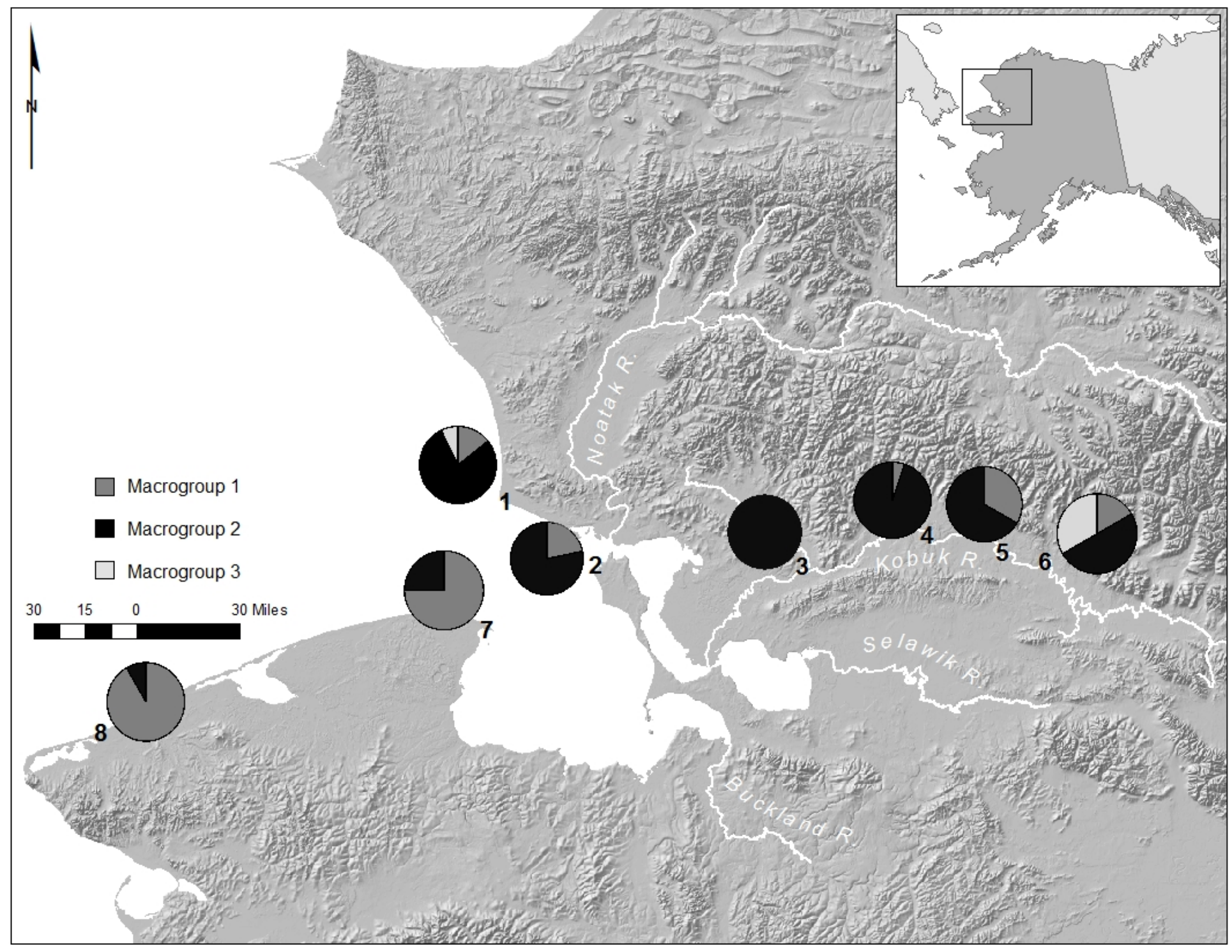

Figure 7. Source distribution by site. Note north to south trend in distribution of macrogroup 1, 2 and 3. Sites are: 1) Cape Krusenstern, 2) Kotzebue, 3) Ekseavik, 4) Ahteut, 5) Onion Portage, 6) Ambler Island, 7) Cape Espenberg, 8) Lopp Lagoon. 


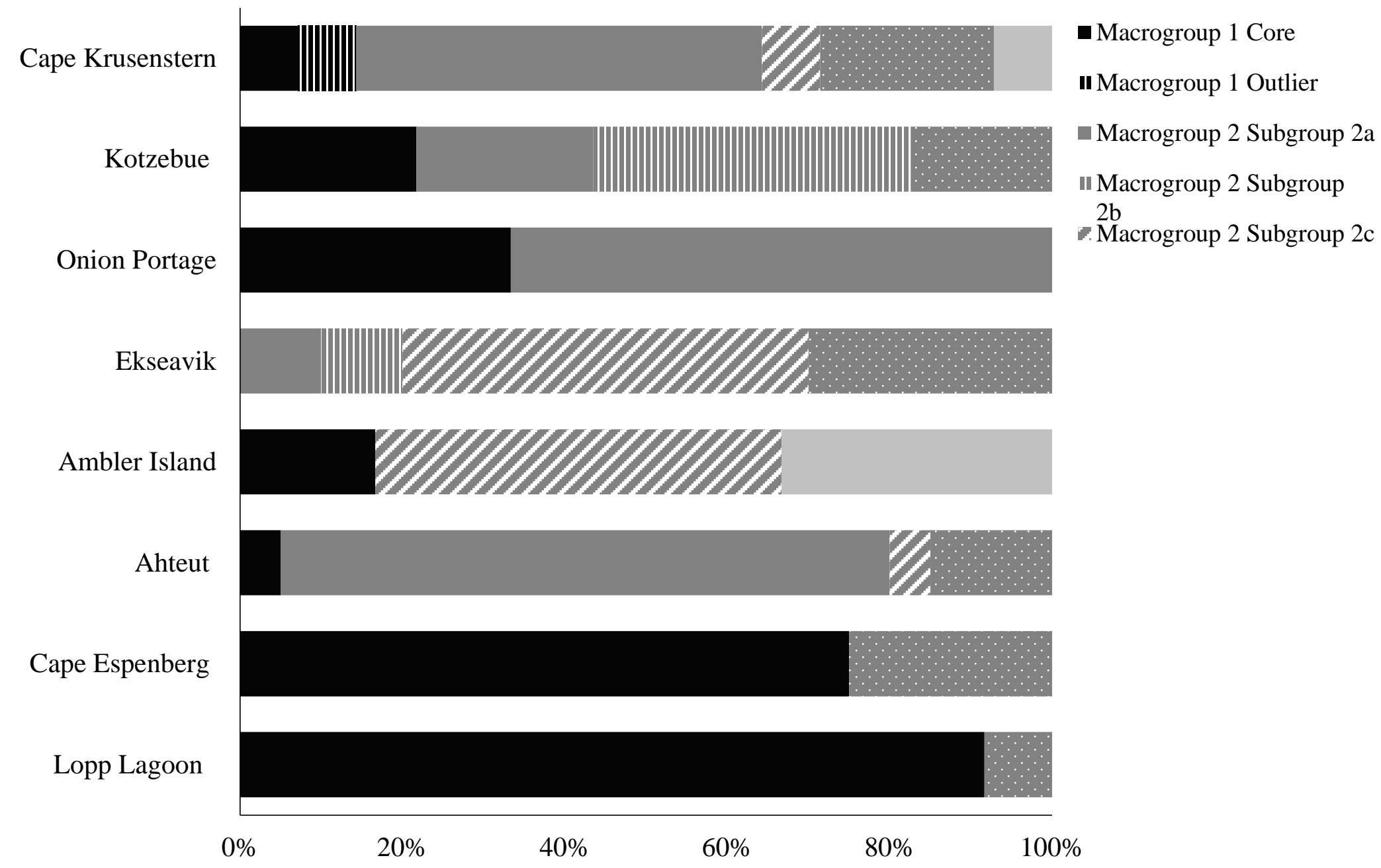

Figure 8. Macrogroup and subgroup distribution by site with northern sites at the top of the y axis and more southern sites towards the bottom of the y axis. 
Table 3. Cross tabulation of group assignments for the Northwest Alaska ceramic database

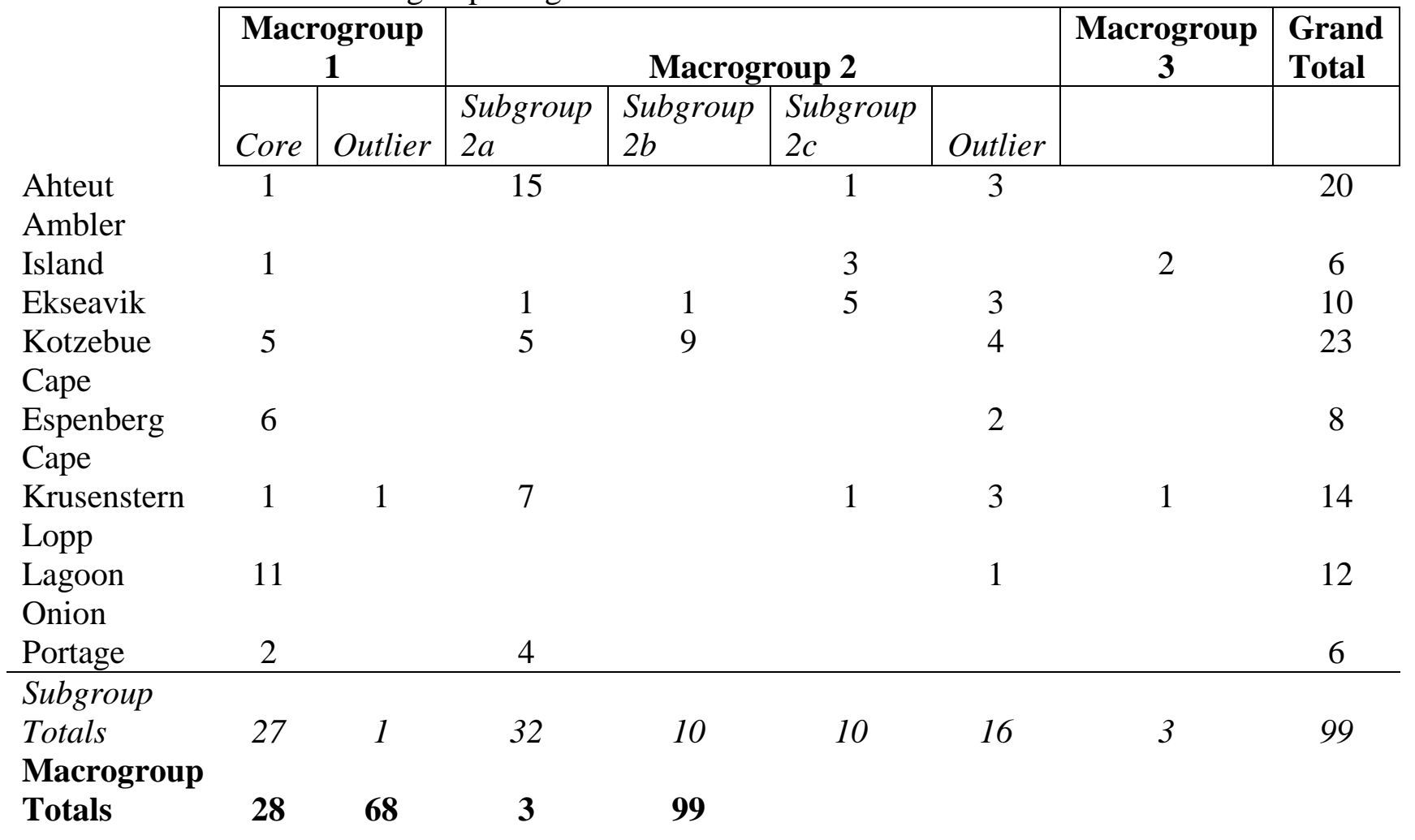


Table 4. Summary of decorative data on rim sherds from Northwest Alaska dataset

\begin{tabular}{|c|c|c|c|c|c|c|c|c|}
\hline Site & Approx. Date & $\begin{array}{l}\text { Undecorate } \\
\text { d }\end{array}$ & $\begin{array}{l}\text { Linear } \\
\text { Stamp }\end{array}$ & $\begin{array}{l}\text { Check } \\
\text { Stamped }\end{array}$ & $\begin{array}{l}\text { Curvilinea } \\
\text { r Stamp }\end{array}$ & $\begin{array}{l}\text { Striate } \\
\text { d }\end{array}$ & $\begin{array}{l}\text { Othe } \\
\text { r }\end{array}$ & Total \\
\hline Ahteut & $750-700$ cal BP & 54 & 0 & 0 & 24 & 0 & 1 & 79 \\
\hline Ambler & 250-190 cal BP & & & & & & & \\
\hline Island & & 10 & 0 & 0 & 0 & 5 & 5 & 20 \\
\hline Ekseavik & $550 \mathrm{cal} \mathrm{BP}$ & 24 & 3 & 0 & 7 & 0 & 1 & 35 \\
\hline Kotzebue & 550-400 cal BP & 89 & 8 & 0 & 4 & 1 & 2 & 104 \\
\hline Cape & 700 cal BP-recent & & & & & & & \\
\hline Espenberg & & 21 & 2 & 0 & 3 & 3 & 3 & 32 \\
\hline Cape & 2900 cal BP - & & & & & & & \\
\hline Krusenstern & recent & 19 & 1 & 1 & 0 & 0 & 0 & 21 \\
\hline Lopp Lagoon & 700-100 cal BP & 10 & 2 & 0 & 0 & 7 & 5 & 24 \\
\hline Onion & 550 cal BP & & & & & & & \\
\hline Portage & & 5 & 0 & 0 & 0 & 0 & 0 & 5 \\
\hline
\end{tabular}




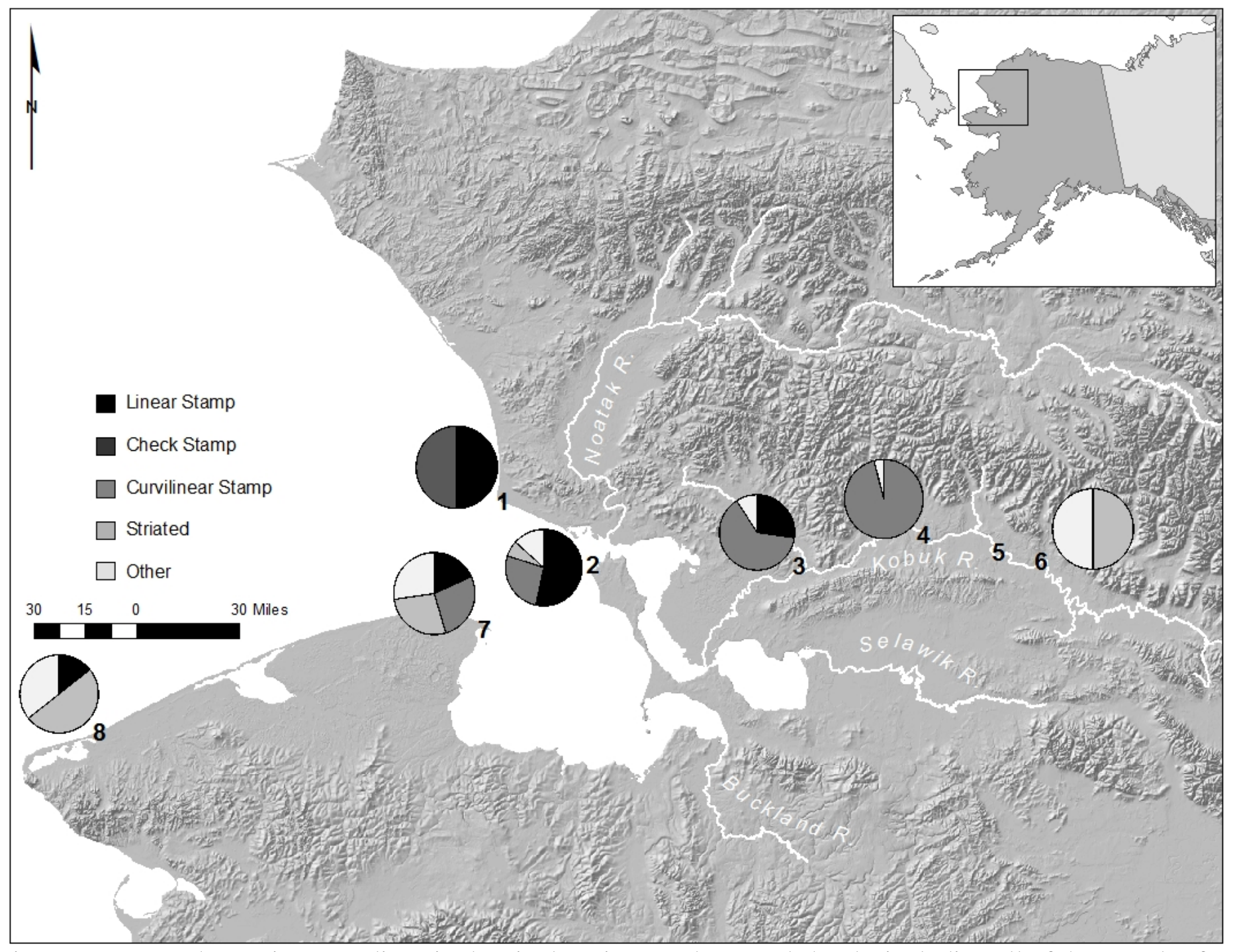

Figure 9. Pottery decorative type diversity by site location. Undecorated sherds, including all of the samples from Onion Portage, omitted from figure. Sites are: 1) Cape Krusenstern, 2) Kotzebue, 3) Ekseavik, 4) Ahteut, 5) Onion Portage, 6) Ambler Island, 7) Cape Espenberg, 8) Lopp Lagoon. 